\title{
Lagged Effects of R\&D Investment on Corporate Market Value: Evidence from Manufacturing Firms Listed in Chinese Stock Markets
}

\author{
Jung Wan LEE ${ }^{1}$
}

Received: March 14, 2020 Revised: May 24, 2020 Accepted: July 03, 2020

\begin{abstract}
The study examines lagged economic effects of research and development (R\&D) investment on the market value of manufacturing firms listed on the Shanghai Stock Exchange or the Shenzhen Stock Exchange in China. This study applies panel data analysis methods to address the following issues: 1) There might be an adjustment lag in the impact of R\&D investment on corporate market value, and 2) Unobserved firm effects must be taken into account. The balanced panel data includes a total of 1,462 observations with 34 cross-sections of manufacturing firms listed on Chinese stock markets and with 27 time-specific quarterly periods from 2007 to 2017 . The results indicate that the R\&D investment of Chinese manufacturing firms tends to yield favorable market value of the firm with some adjustments to time. The results show that R\&D investment exhibits a strong positive impact on their market value of manufacturing firms in Chinese stock markets. Moreover, R\&D investment has a positive time-lag effect on the market value of the firm. Interestingly, the R\&D investment of Chinese manufacturing firms generate a relatively constant positive effect on their market value, supporting the notion that the corresponding returns of R\&D investment for such firms yield lagged but added market values.
\end{abstract}

Keywords : R\&D Investment, R\&D Intensity, Firm Performance, Market Value, Lagged Effects

JEL Classification Code : M11, M21, M41, O32, O33

\section{Introduction}

In today's competitive business landscape, firms must seek opportunities both internally and externally. Whether a resource, a process, or a technology is concerned, a firm must remain agile enough to adapt to the trajectory of everchanging market needs. Nadarajah and Kadir (2014) claim that it can be more beneficial for firms to use operational process change or change management to gain a sustainable competitive advantage. They explained that capabilities could be created through the use of technology, people, processes, or available assets. Chen and Chen (2013) focus on resource synergy, which occurs when a firm continues

${ }^{1}$ First Author and Corresponding Author. School of International Economics and Trade, Anhui University of Finance and Economics (AUFE), China [Postal Address: 962 Caoshan Road, Bengbu City, Anhui Province, China 233030] Email: jungwan.lee@aufe.edu.cn

(c) Copyright: The Author(s)

This is an Open Access article distributed under the terms of the Creative Commons Attribution Non-Commercial License (http://Creativecommons.org/licenses/by-nc/4.0/) which permits unrestricted noncommercial use, distribution, and reproduction in any medium, provided the original work is properly cited. to utilize and invest in its resources to create a competitive advantage. This enables the firm to accumulate further financial and valuable resources. In this manner technological innovation allows firms to develop new products, create a competitive advantage, and ultimately succeed in the everchanging market. In a similar vein, technological innovation i.e. research and development (R\&D) is considered as a very important part of dynamic capabilities.

To maintain a leading and competitive position, there is a growing tendency for firms to adopt newer and disruptive technologies so thus the firm promotes technological innovation. Besides the internal demand, the external environment such as new policy encouragement and competitive pressure could also be considered as a major motivation for technological innovation. The tendency of technological innovation is based on the strategic decision about the extent to which technological innovation affects the firm production process and operational efficiency and, thus, results in bottom-line benefits in the short-term and also leads to sustainable performance in the market. In this regard, top management likely decides on a strategic balance between short-term and long-term benefits for their technological innovation. 
Other than the strategy alignment, costs are also another main concern in R\&D investment. With the expectation from shareholders to gain the highest return with the least risk and loss, corporations unlikely want to generate negative cash flows from their investment. Therefore, their investment in R\&D should yield some expected bottom-line benefits. In many cases, the limitation in the alignment of costs and benefits is the time frame, where the costs are immediate but the benefits are not often realized quickly.

This study aims to provide plausible answers to the question: "What is the time lag of $R \& D$ investment on the market value of manufacturing firms in Chinese stock markets?" People often see a delay between an economics action and a consequence, known as a time lag. An impact of time lags is that the economic effect of decisions may be more difficult to quantify because it takes a period of time to actually occur. Both financial performance indicators (i.e. accounting-based and market-based measurements) and R\&D investment may influence the value of the company in the market. An issue standing in the way of the effectiveness of each of R\&D investment is the time lag that occurs from the R\&D investment to the actual economic returns of it. It is assumed that R\&D investment normally takes a certain amount of time to have an economic effect on the market value of the firm.

\section{Literature Review and Hypothesis}

Technological innovation through $R \& D$ investment in manufacturing firms is important to the organizational innovation and to develop dynamic capabilities for a longterm success of a firm (Gentry \& Shen, 2013). In this way R\&D investment plays an important role in creating competitive advantages and exploring growth opportunities. Berry and Taggart (1998) highlight the importance of a strong strategic plan when taking a decision on R\&D investment. Sakakibara (1997) assesses the spillover effects of R\&D investment in relation to skill sharing and cost sharing. The skill-sharing motive increases $R \& D$ investment of a firm because it provides the management with an additional opportunity for possible participation in cooperative R\&D (Hanel \& StPierre, 2002). In this way, technological innovation can affect a firm's operational competence. Cooper and Kleinschmidt (2007) support technological innovation proficiency that a successful company must have a good strategy for R\&D. Technological innovation through $R \& D$ investment can positively spin out new products or process innovation.

Hanel and St-Pierre (2002) find a positive correlation between technological innovation and firm performance in particular with the stock price of a firm. Some studies also report that those firms that invest a large portion of their revenues in technological innovation tend to yield higher levels of bottom-line benefits than those firms that invest smaller portion in R\&D (e.g., Artz, Norman, Hatfield, \& Cardinal, 2010; Yeh, Chu, Sher, \& Chiu, 2010). Zhao and Zou (2002) also claim that the level of R\&D investment is positively correlated with firm growth rates. Nobelius (2004) finds that companies that succeed in commercializing new technology have higher market shares while technological innovation can result in a high level of uncertainty and poor rates of return (Hill \& Jones, 2012).

Mudambi and Swift (2013) and Kor (2006) claim that top management directly affects decision-making on the levels of technological innovation and R\&D investment. Managers likely cut the level of R\&D investment when they are under pressure to meet profitability forecasts (Gentry \& Shen, 2013). According to Cuervo-Cazurra and Un (2010), when a firm has sufficient internal resources, but lacks external resources the firm is likely to increase the level of R\&D investment. Arora, Belenzon and Rios (2014) claim that centralized firms can reduce the internal traction costs associated with technological innovation and invest more in R\&D than decentralized firms (Argyres \& Silverman, 2004). Chen and Chen (2013) claim that small firms have more difficulty in competing successfully with larger firms due to their limited resources, capabilities, legitimacy and social ties. Ceccagnoli (2009) claims that the ownership of specialized assets i.e. patents increases the level of R\&D investment. Furthermore, technology and market uncertainty (Oriani \& Sobrero, 2008), greater access to external knowledge (Macher \& Boerner, 2012) and dynamic capabilities (Helfat, 2012) affect the level of R\&D investment.

Sakakibara (2002) finds evidence that industry characteristics affect the contribution ratio of a firm in technological innovation and so the level of R\&D investment significantly varies across industries. Much literature reports that high-tech firms invest more in technological innovation and place a higher value on R\&D for product innovation (e.g., Grinstein \& Goldman, 2006; Short, Ketchen, Palmer, \& Hult, 2007). Nunes, Serrasqueiro and Leitão (2012) report that R\&D investment stimulates the growth of high-tech small and medium sized enterprises (SMEs) at higher levels, while R\&D investment restricts the growth of non-high-tech SMEs regardless of the level of R\&D investment using a sample of SMEs in manufacturing industries. It is said that high-tech industries put more resources into technological innovation while low-tech industries put more effort into marketing efforts (Chan \& Fang, 2006). Robertson and Patel (2007) claim that non-high-tech firms are major consumers of high-tech products and therefore can benefit from technological innovation in the market. However, high levels of capital expenditure and sales in the high-tech industry are more likely to be dependent on the country-specific context and the macroeconomic forces of the nation's economic structure (Neelankavil \& Alaganar, 2003). Firms that have strategic plans for technological innovation utilize strategic 
resources funded by local governments more effectively and have higher success rates than an average success rate (Wilbon, 2002). In sum, the organizational characteristics and industry characteristics affect firms' decisions on the level of R\&D investment and accordingly result in different market performance.

A study reports that companies can maximize their valueadded products to customers and provide a competitive advantage in the marketplace by selecting appropriate technological innovation (Hill \& Jones, 2012). According to Ortega (2010), technological innovation has substantial positive effects on both the competitive strategies and the economic performance of a firm. A considerable amount of literature has sought to explain spillover effects of technological innovation on firm performance (Cincera, 2005). However, the empirical evidence from these studies is still mixed. Note that as investing in R\&D increases sales can rise up but the better performance of profitability ratios is not guaranteed. For example, Coad and Rao (2010) claim that firms appear to increase their total R\&D expenditure following growth in sales (Morbey \& Reithner, 1990) and employment (Di Cintio, Ghosh, \& Grassi, 2017). Bardhan, Krishnan and Lin (2013) claim that the interaction effect of R\&D investment and technological innovation on Tobin's Q is positive and significant after controlling for other firmspecific effects. As such it is difficult to measure accurately the spillover effects of technological innovation on firm performance. Increased uncertainty and the time lag involved in realizing the profitability from technological innovation make it more difficult to measure the spillover effects of technological innovation on firm performance (Cameron, Proudman, \& Redding, 2005; Mahlich \& Roediger-Schluga, 2006).

However, it is noteworthy that the bias of positive relationship between $R \& D$ investment and their return appears to be particularly strong in the part of the literature due to controlling of unobserved firm fixed effects (Møen \& Thorsen, 2017). Loch and Tapper (2002) claim that how a high level of uncertainty of R\&D project assumptions and long lag time makes a simple model inadequate. A study reports that a lag period exists before commercialization of new technology while technology transfer has a more rapid effect on product innovation (Cameron et al., 2005). The common issues of risk and reward cause managers to make simple positive decisions instead of decisions favoring highpotential, high-risk and long-term projects. In fact, strategies must identify the trade-offs and priorities among conflicting goals. According to Yeh et al. (2010), there is a level exceeding that technological innovation does not always guarantee proportional performance and rewards. Branstetter and Chen (2006) claim that Taiwanese manufacturing firms have a preference for buying technology as opposed to developing internal R\&D investment.
Lee and Choi (2015) claim that the time-lag effect of R\&D investment with regard to Tobin's $Q$ tends to be occasionally positive for Korean pharmaceutical companies on their market value. Rouvinen (2002) claims that R\&D investment causes an increase in productivity, however, productivity responds to changes in the level of $R \& D$ investment with a considerable lag. Kafouros and Wang (2008) claim that the effect of R\&D investment is statistically significant and relatively high in manufacturing industries, thereby suggesting that the effect of R\&D investment tends to last long. The results, however, vary across organizations depending on both firm size and the technological opportunities that the company faces (Capasso, Treibich, \& Verspagen, 2015; Wang, Zhao, \& Zhang, 2016; Xu \& Sim, 2018). Donelson and Resutek (2012) claim that the excess returns of $R \& D$ firms are part of the larger value/growth anomaly, while future earnings are positively associated with current R\&D, errors in earnings expectations by investors are not always related to the R\&D intensity of the firm.

This study aims to investigate the lagged economic effect of $R \& D$ investment on the market value of the firm. The negative relationship implicates the thinking of neoclassical economist, according to which large R\&D investment has a competitive disadvantage due to the incurred costs that could have been avoided by the firm. Thus, it results in the reduction of their profits. The argument for positive relationship is that the actual costs of $R \& D$ are covered by the benefits. Based on the statement above, the study has generated the following hypotheses for further verification.

H1: There might be an adjustment lag in the impact of $R \& D$ investment on the market value of the firm.

H2: Income (earnings) is positively related to the market value of the firm.

H3: Risk ratio is negatively related to the market value of the firm.

\section{Research Methods}

\subsection{Data and Descriptive Statistics}

The sample data includes a total of 34 manufacturing firms listed on the Shanghai Stock Exchange or the Shenzhen Stock Exchange over a 11-year period, 2007-2017. The balanced panel data includes a total of 1,462 observations with 34 cross sections of manufacturing firms listed on Chinese stock markets and with 27 time-specific periods from 1st quarter of March 2007 to 4th quarter of December 2017. R\&D intensity is used here as a proxy for the level of R\&D investment and technological innovation of a firm. $R \& D$ intensity refers to the ratio of the book value of $R \& D$ expenditure to the total sales. Table 1 gives descriptive statistics for some important variables used in the study. 
Table 1: Descriptive Statistics per Quarter between 2007-2017

\begin{tabular}{|l|c|c|c|c|}
\hline & Market value & R\&D intensity & Income & Debt ratio \\
\hline Mean & $6.26 \mathrm{E}+09$ & 0.015 & $2.39 \mathrm{E}+08$ & 1.769 \\
\hline Median & $4.61 \mathrm{E}+09$ & 0.012 & $2.52 \mathrm{E}+08$ & 1.890 \\
\hline Maximum & $25.20 \mathrm{E}+09$ & 0.037 & $5.39 \mathrm{E}+08$ & 2.226 \\
\hline Minimum & $2.26 \mathrm{E}+09$ & 0.002 & 35297003 & 0.842 \\
\hline Std. Dev. & $5.20 \mathrm{E}+09$ & 0.010 & $1.13 \mathrm{E}+08$ & 0.345 \\
\hline Observations & 1462 & 1462 & 1462 & 1462 \\
\hline Cross sections & 34 & 34 & 34 & 34 \\
\hline
\end{tabular}

Table 2: Results of Correlation between Key Variables

\begin{tabular}{|l|c|c|c|}
\hline & Market value & R\&D intensity & Income \\
\hline R\&D intensity & $0.032[1.228]$ & & \\
\hline Income & $0.272[10.823]^{\star * *}$ & $0.726[40.437]^{\star \star *}$ & $-0.064[-2.458]^{\star *}$ \\
\hline Debt & $-0.425[-17.986]^{\star \star *}$ & $-0.409[-17.174]^{\star * *}$ & \\
\hline
\end{tabular}

Correlation is significant at the 0.05 level $\left(* *, p<0.05\right.$ and $\left.{ }^{* * *}, p<0.01\right)$

Values in square brackets [ ] are t-statistics.

Table 3: Results of Panel Unit Root Tests

\begin{tabular}{|l|c|c|c|c|}
\hline \multicolumn{1}{|c|}{ Time series } & Market value & R\&D intensity & Income & Debt \\
\hline \multirow{2}{*}{ Test methods } & $\begin{array}{c}\text { Level } \\
\text { 1st difference }\end{array}$ & $\begin{array}{c}\text { Level } \\
\text { 1st difference }\end{array}$ & $\begin{array}{c}\text { Level } \\
\text { 1st difference }\end{array}$ & 1st difference \\
\hline \multirow{2}{*}{ Levin et al. } & $-8.966^{* * *}$ & $-24.518^{* * *}$ & $-39.590^{* * *}$ & $-8.751^{* * *}$ \\
\hline \multirow{2}{*}{ Im et al. } & $-44.188^{* * *}$ & $-32.465^{* * *}$ & $-42.225^{* * *}$ & $-28.831^{* * *}$ \\
\hline \multirow{2}{*}{ Fisher-ADF } & $-9.453^{* * *}$ & $-27.228^{* * *}$ & $-39.986^{* * *}$ & $-5.615^{* * *}$ \\
& $-39.753^{* * *}$ & $-39.019^{* * *}$ & $-45.391^{* * *}$ & $-25.439^{* * *}$ \\
\hline \multirow{2}{*}{ Fisher-PP } & $209.204^{* * *}$ & $728.593^{* * *}$ & $1111.550^{* * *}$ & $127.725^{* * *}$ \\
& $1097.371^{* * *}$ & $1077.710^{* * *}$ & $1234.690^{* * *}$ & $668.840^{* * *}$ \\
\hline
\end{tabular}

Probability values for rejection of the null hypothesis of a unit root are employed at the 0.05 level $(* * *, p<0.01)$.

\subsection{Correlation Analysis}

Table 2 presents the correlations between the explanatory variables and the market value of the firm. Although the variance inflation factor is not presented here due to the table space limit, this study finds that the problem of multicollinearity does not appear to exist. Table 2 indicates that R\&D intensity has no correlation with the market value $(p>0.05)$, but positive correlation with income growth of the firm $(p<0.01)$.

\subsection{Unit Root Tests}

The literature suggests that panel-based unit root tests have higher power than unit root tests based on individual time series (Im, Pesaran, \& Shin, 2003; Levin, Lin and Chu, 2002; Maddala \& Wu, 1999). For the purpose of testing of unit root, there are two natural assumptions about the autoregressive coefficient, $\gamma_{i}$ First, one can assume that the persistence parameters are common across cross-sections, so that $\gamma_{\mathrm{i}}=\gamma$ for all cross-sections $i$. The Levin et al. (2002) unit root test employs this assumption and thus assumes that there is a common unit root process as the null hypothesis (alternative: there is no unit root) so that the autoregressive coefficient is identical across cross-sections. Alternatively, one can allow $\gamma_{\mathrm{i}}$ to vary freely across cross-sections. This study also employs two panel based unit root tests: Fishertype augmented Dickey-Fuller test (Im et al., 2003) and Fisher-type Phillips-Perron test (Maddala \& Wu, 1999) to 
test stationarity of the time series data. The probabilities for the two Fisher-type unit root tests were computed using an asymptotic chi-square distribution. All other tests assume asymptotic normality.

Table 3 displays the numeric values of the panel-based unit root tests for each time series. The panel unit root tests were conducted with the selection of individual effects that wish to include individual fixed effects, with the NeweyWest automatic bandwidth selection and Bartlett kernel estimation method, and with the selection of maximum lags of 2. At the level, all of the null hypothesis can be rejected at the 0.01 significance level. This indicates all of the time series are stationary at the level in which there is no unit root.

\section{Results}

There are several types of panel data analytic models, including fixed effects and random effects models. The presence of cross-section and period specific effects may be handled using fixed or random effects methods. The fixed effects portions of specifications are handled using orthogonal projections. In the simple one-way fixed effects specification and the balanced two-way fixed effects specification, these projections employ the same approach of removing cross-section or period specific means from the dependent variable and exogenous regressors, and then performing the specified regression using the demeaned data. Alternatively, the random effects specifications assume that the corresponding effects are a realization of independent random variables with mean zero and finite variance. Most importantly, the random effects specification assumes that the effect is uncorrelated with the idiosyncratic residual (Baltagi, 2005).

The Hausman test is used to determine which of the two methods should be employed. It tests whether the unique errors are correlated with the regressors; the null hypothesis

Table 4: Results of Panel Regression Analysis

\begin{tabular}{|c|c|c|}
\hline Cross section & Fixed Effects & Random Effects \\
\hline Estimation method & Pooled Least Squares & $\begin{array}{c}\text { Pooled EGLS } \\
\text { (cross-section random effects) }\end{array}$ \\
\hline R\&D intensity & $1.431[37.151]^{\star * *}$ & $1.431[37.149]^{\star * *}$ \\
\hline R\&D intensity(t-1) & $0.778[22.204]^{\star \star *}$ & $0.772[22.161]^{\star \star *}$ \\
\hline R\&D intensity(t-2) & $0.448[12.839]^{\star * *}$ & $0.446[12.788]^{\star \star *}$ \\
\hline R\&D intensity(t-3) & $0.418[12.153]^{\star \star *}$ & $0.416[12.087]^{\star \star *}$ \\
\hline Income & $0.193[96.664]^{\star * *}$ & $0.193[96.727]^{\star * *}$ \\
\hline Debt & $-0.040[-5.702]^{\star * *}$ & $-0.038[-5.472]^{\star * *}$ \\
\hline Constant & 16.635 & 16.632 \\
\hline R-squared & 0.885 & 0.195 \\
\hline Adjusted R-squared & 0.885 & 0.195 \\
\hline F-statistic & $9130.462^{* * *}$ & $2959.413^{* * *}$ \\
\hline Durbin-Watson statistic & 1.170 & 1.168 \\
\hline Included observations & 1360 after adjustments & 1215 after adjustments \\
\hline Included cross sections & 34 & 34 \\
\hline Total pool observations & 46240 & 46240 \\
\hline \multirow[t]{2}{*}{ Effects test specification } & $\begin{array}{l}\text { Redundant cross section fixed effects }(\text { d.f. }=33) \\
\text { F-statistic }=4963.829^{* * *}\end{array}$ & $\begin{array}{l}\text { Cross section random effects } \\
\text { Rho }=0.760\end{array}$ \\
\hline & $\begin{array}{l}\text { Redundant cross section fixed effects }(\mathrm{d} . \mathrm{f} .=33) \\
\text { Chi-square statistic }=70014.666^{\star * *}\end{array}$ & $\begin{array}{l}\text { Idiosyncratic random effects } \\
\text { Rho }=0.240\end{array}$ \\
\hline Hausman test & $\begin{array}{l}\text { Cross section random effects Chi-square statistic } \\
=43 \cdot 120^{* * *}(\text { d.f. }=6)\end{array}$ & \\
\hline
\end{tabular}

Regression model: Market value $=\mathrm{R} \& \mathrm{D}+\mathrm{R} \& \mathrm{D}(\mathrm{t}-1)+\mathrm{R} \& \mathrm{D}(\mathrm{t}-2)+\mathrm{R} \& \mathrm{D}(\mathrm{t}-3)+$ Income + Debt

The numeric values in [ ] are t-statistics.

Probabilities for rejection of the null hypothesis are employed at the 0.05 significance level $\left({ }^{* * *}, p<0.01\right)$. 
is that they are not. Probabilities are computed using the chisquared distribution. If the procedure of the statistical test shows the null hypothesis is not rejected, the random effects method is chosen. The result of the Hausman test indicates that the fixed effects model is more robust for the case of the regression specifications with the current balanced panel data (cross section random chi-square statistic $=43.120$, $\mathrm{p}$-value $<0.01$ ). Table 4 reports the results of the panel regression analysis. In Table 4, the numeric values in the cells are coefficients of regressors, which indicate short-run elasticity of the endogenous variable for the dependent variable.

In testing hypothesis 1 that there are lagged effects of $R \& D$ investment on the market value of the firm, Table 4 indicates that the hypothesis is supported at the 0.01 level. The results suggest that a one percent rise in $R \& D$ investment increases the market value by 1.43 percent for the concurrent time period, and afterwards gradually decreases its impact, but still increases by 0.77 percent with a one-period time $\operatorname{lag}(-1)$, by 0.44 percent with a two-period time lag(-2), and by 0.41 percent with a three-period time $\operatorname{lag}(-3)$.

In testing hypothesis 2 that income (earnings) is related to the market value of the firm, Table 4 indicates that the hypothesis is supported at the 0.01 level. The results suggest that a one percent rise in income increases the market value by 0.19 percent.

In testing hypothesis 3 that risk ratio is related to the market value of the firm, Table 4 indicates that the hypothesis is supported at the 0.01 level. The result suggests that a one percent rise in risk ratio decreases the market value by 0.04 percent.

\section{Discussion and Recommendations}

The findings of the study suggest that the R\&D investment of Chinese manufacturing firms tends to yield favorable market value of the firm with some adjustments to time. An interesting finding of this study is that Chinese manufacturing firms seem to allocate significantly little resources for $R \& D$ investment (average $R \& D$ intensity was 0.02 , with standard deviation of 0.01 ). A plausible explanation is that as expenditure on $R \& D$ increases sales increase but there is no guarantee of income gains as such. The findings suggest that Chinese manufacturing firms may want to allocate little resources to R\&D and technological innovation for the short-term profitability purpose; however, it is desirable for them to allocate more resources to $R \& D$ and technological innovation for their future market value and their long-term business sustainability.

This study provides important implications for our understanding of the complex lags effects of $R \& D$ input on output as well as policy-makers for designing and implementing $\mathrm{R} \& \mathrm{D}$ and innovation strategies. The findings of the study provide some insights that R\&D investment and technological innovation maybe result in unfavorable firm financial performance in the short-term but eventually contributes to build up better innovation capabilities and competitive advantages in the long-term. Companies who are planning ahead and want to maintain sustainable growth may want to avoid unprofitable returns. Note that sustainable growth and increased income of the firm are largely dependent on R\&D investment and technological innovation capabilities. Managing the sustainable growth is important so that companies may want to avoid adding pressure on financial resources and stretching their financial leverage in the short-term. However, the findings suggest that firms should allocate more resources on $R \& D$ investment and technological innovation for the long-term continued success, expecting that their $R \& D$ investment enables the firm to forecast positive future equity and favorable firm performance in the market.

From the findings of this study it is clear that the strong R\&D investment and technological innovation is a crucial catalyst to develop dynamic capabilities, which can create and maintain competitive advantages for the firm in the market. The ability to obtain a competitive advantage lies within companies' unique attributes, which dictate how they will identify and respond to opportunities. When companies pay attention to $R \& D$ investment and technological innovation positively, they will be more adept in responding to situations and seizing opportunities. These R\&D investment and technological innovation capabilities can lead companies to realize greater market value and establish a greater connection with their customers and investors eventually. In conclusion, the firms that develop successfully such technological innovation capabilities through R\&D investment allow them to move more nimbly in today's dynamic business environments. As such the odds are better that they will continue sustainable growth in the market.

\section{Conclusions}

The results of the study indicate that the R\&D investment of Chinese manufacturing firms tends to yield favorable market value of the firm with some adjustments to time. The results show that $R \& D$ investment exhibits a strong positive impact on their market value of the firm in Chinese stock markets. Moreover, R\&D investment has a positive time-lag effect on the market value of the firm. In addition, R\&D strategic investments of Chinese manufacturing firms generate a relatively constant positive effect on their market value, supporting the notion that the corresponding returns of R\&D investment for such firms yield lagged but constantly positive market value.

One of limitations of the study is that the results can be biased due to the selection issue of samples from a single country, which means that the country-specific 
characteristics can be a part of the bias. Further tests using a comparable number of samples with more longitudinal data and comparing multiple economies may produce different results.

\section{References}

Argyres, N. S., \& Silverman, B. S. (2004). R\&D, organization structure, and the development of corporate technological knowledge. Strategic Management Journal, 25(8-9), 929-958.

Arora, A., Belenzon, S., \& Rios, L. A. (2014). Make, buy, organize: The interplay between research, external knowledge, and firm structure. Strategic Management Journal, 35(3), 317-337.

Artz, K. W., Norman, P. M., Hatfield, D. E., \& Cardinal, L. B. (2010). A longitudinal study of the impact of R\&D, patent, and product innovation on firm performance. Journal of Product Innovation Management, 27, 725-740.

Baltagi, B. H. (2005). Econometric Analysis of Panel Data (3 $3^{\text {rd }}$ ed.). West Sussex, England: John Wiley \& Sons.

Bardhan, I., Krishnan, V., \& Lin, S. (2013). Research note - Business value of information technology: Testing the interaction effect of IT and R\&D on Tobin's Q. Information Systems Research, 24(4), 1147-1161.

Berry, M. M. J., \& Taggart, J. H. (1998). Combining technology and corporate strategy in small high tech firms. Research Policy, 26, 883-895.

Branstetter, L., \& Chen, J. R. (2006). The impact of technology transfer and $\mathrm{R} \& \mathrm{D}$ on productivity growth in Taiwanese industry: Microeconometric analysis using plant and firmlevel data. Journal of Japanese International Economies, 20, 177-192.

Cameron, G., Proudman, J., \& Redding, S. (2005). Technological convergence, R\&D, trade and productivity growth. European Economic Review, 49, 775-897.

Capasso, M., Treibich, T., \& Verspagen, B. (2015). The mediumterm effect of R\&D on firm growth. Small Business Economics, 45(1), 39-62.

Ceccagnoli, M. (2009). Appropriability, preemption, and firm performance. Strategic Management Journal, 30(1), 81-98.

Chan, S. C., \& Fang, W. (2006). A study on the factors of manufacturer profitability: The moderating effect of different industries. Journal of American Academy of Business, 8(2), 138-144.

Chen, J.-K., \& Chen, I.-S. (2013). A theory of innovation resource synergy. Innovation: Management, Policy \& Practice, 15(3), 368-392.

Cincera, M. (2005). 'Firms' productivity growth and R\&D spillovers: An analysis of alternative technological proximity measures. Economics of Innovation and New Technology, 14, 657-682.

Coad, A., \& Rao, R. (2010). Firm growth and R\&D expenditure. Economics of Innovation and New Technology, 19(2), 127-145.
Cooper, R. G., \& Kleinschmidt, E. J. (2007). Winning businesses in product development: The critical success factors. ResearchTechnology Management, 50(3), 52-66.

Cuervo-Cazurra, A., \& Un, C. A. (2010). Why some firms never invest in formal R\&D. Strategic Management Journal, 31(7), 759-779.

Di Cintio, M., Ghosh, S., \& Grassi, E. (2017). Firm growth, R\&D expenditures and exports: An empirical analysis of Italian SMEs. Research Policy, 46(4), 836-852.

Donelson, D. C., \& Resutek, R. J. (2012). The effect of R\&D on future returns and earnings forecasts. Review of Accounting Studies, 17(4), 848-876, DOI: 10.1007/s11142-011-9179-y.

Gentry, R. J., \& Shen, W. (2013). The impacts of performance relative to analyst forecasts and analyst coverage on firm R\&D intensity. Strategic Management Journal, 34(1), 121-130.

Grinstein, A., \& Goldman, A. (2006). Characterizing the technology firm: An exploratory study. Research Policy, 35, 121-143.

Hanel, P., \& St-Pierre, A. (2002). Effects of R\&D spillovers on the profitability of firms. Review of Industrial Organization, 20(4), 305-322.

Helfat, C. E. (2012). Know-how and asset complementarity and dynamic capability accumulation: The case of R\&D. Strategic Management Journal, 18(5), 339-360.

Hill, C. W. L., \& Jones, G. R. (2012). Strategic management: an integrated approach (10th ed.). Nashville, TN: South-Western College Publishing.

Im, K. S., Pesaran, M. H., \& Shin, Y. (2003). Testing for unit roots in heterogeneous panels. Journal of Econometrics, 115(1), 53-74.

Kafouros, M. I., \& Wang, C. (2008). The Role of Time in Assessing the Economic Effects of R\&D. Industry and Innovation, 15(3), 233-251, https://doi.org/10.1080/13662710802041638.

Kor, Y. Y. (2006). Direct and interaction effects of top management team and board compositions on R\&D investment strategy. Strategic Management Journal, 27(11), 1081-1099.

Lee, M., \& Choi, M. (2015). Analysis on Time-Lag Effect of Research and Development Investment in the Pharmaceutical Industry in Korea. Osong Public Health Research Perspective, 6(4), 241-248. DOI: 10.1016/j.phrp.2015.07.001.

Levin, A., Lin, C. F., \& Chu, C. J. (2002). Unit root tests in panel data: asymptotic and finite-sample properties. Journal of Econometrics, 108, 1-24.

Loch, C. H., \& Tapper, V. A. S. (2002). Implementing a strategydriven performance measurement system for an applied research group. Journal of Product Innovation Management, 19, 185-198.

Macher, J. T., \& Boerner, C. (2012). Technological development at the boundaries of the firm: A knowledge-based examination in drug development. Strategic Management Journal, 33(9), 1016-1036.

Maddala, G. S., \& Wu, S. (1999). A comparative study of unit root tests with panel data and a new simple test. Oxford Bulletin of Economics and Statistics, 61(S1), 631-652. 
Mahlich, J., \& Roediger-Schluga, T. (2006). The determinants of pharmaceutical R\&D expenditures: Evidence from Japan. Review of Industrial Organization, 28(2), 145-164.

Møen, J., \& Thorsen, H. S. (2017). Publication bias in the returns to R\&D literature. Journal of the Knowledge Economy, 8(3), 987-1013.

Morbey, G. K., \& Reithner, R. M. (1990). How R\&D affects sales growth, productivity and profitability. Research-Technology Management, 33(3), 11-14.

Mudambi, R., \& Swift, T. (2013). Knowing when to leap: Transitioning between exploitative and explorative R\&D. Strategic Management Journal, 35(1), 126-145.

Nadarajah, D., \& Kadir, S. L. (2014). A review of the importance of business process management in achieving sustainable competitive advantage. TQM Journal, 26(5), 522-531.

Neelankavil, J. P., \& Alagnar, V. T. (2003). Strategic resource commitment of high technology firms: An international comparison. Journal of Business Research, 56, 493-502.

Nobelius, D. (2004). Towards the sixth generation of R\&D management. International Journal of Project Management, $22,369-375$.

Nunes, P. M., Serrasqueiro, Z., \& Leitão, J. (2012). Is there a linear relationship between $R \& D$ intensity and growth? Empirical evidence of non-high-tech vs. high-tech SMEs. Research Policy, 41(1), 36-53.

Oriani, R., \& Sobrero, M. (2008). Uncertainty and the market valuation of R\&D within a real options logic. Strategic Management Journal, 29(4), 343-361.

Ortega, M. J. R. (2010). Competitive strategies and firm performance: Technological capabilities' moderating roles. Journal of Business Research, 63(12), 1273-1281.
Robertson, P. L., \& Patel, P. R. (2007). New wine in old bottles: technological diffusion in developed economies. Research Policy, 36, 708-721.

Rouvinen, P. (2002). R\&D - Productivity dynamics: causality, lags, and 'dry holes'. Journal of Applied Economics, 5(1), 123-156.

Sakakibara, M. (1997). Heterogeneity of firm capabilities and cooperative research and development: An empirical examination of motives. Strategic Management Journal, 18, 143-164.

Sakakibara, M. (2002). Formation of R\&D consortia: Industry and company effects. Strategic Management Journal, 23(11), 10331050 .

Short, J. C., Ketchen, D. J., Palmer, T. B., \& Hult, G. T. M. (2007). Firm, strategic group, and industry influences on performance. Strategic Management Journal, 28(2), 147-167.

Wang, D., Zhao, X., \& Zhang, Z. (2016). The Time Lags Effects of Innovation Input on Output in National Innovation Systems: The Case of China. Discrete Dynamics in Nature and Society, [Online Journal] Article ID 1963815, http://dx.doi. org/10.1155/2016/1963815.

Wilbon, A. D. (2002). Predicting survival of high-technology initial public offering firms. The Journal of High Technology Management Research, 13(1), 127-141.

Xu, J., \& Sim, J.-W. (2018). Characteristics of Corporate R\&D Investment in Emerging Markets: Evidence from Manufacturing Industry in China and South Korea. Sustainability, 10(9). [Online Journal] Article ID 3002, https://doi.org/10.3390/ su10093002.

Yeh, M. L., Chu, H. P., Sher, P. J., \& Chiu, Y. C. (2010). R\&D intensity, firm performance and the identification of the threshold: Fresh evidence from the panel threshold regression model. Applied Economics, 42, 389-401. 